\title{
Cerebral palsy litigation after fifty years: A hoax on you
}

\author{
THOMAS P SARTWELLE, JAMES C JOHNSTON, BERNA ARDA, MEHILA ZEBENIGUS
}

\begin{abstract}
The worldwide cerebral palsy (CP) litigation crisis is predicated on the hoax that electronic foetal monitoring (EFM) predicts and prevents $C P$. There are decades of research disproving this hoax, yet EFM continues to be performed in the vast majority of labours in developed countries with resultant harm to mothers and babies alike through unnecessary caesarean sections with all of the attendant complications and ramifications of that procedure. This article reviews the history and evolution of EFM, explores the reasons for its misuse, discusses how obstetricians have abandoned their ethical mandate by failing to obtain informed consent for EFM, and proposes a realistic, practical solution that would effectively change the standard of care.
\end{abstract}

Keywords: Medical ethics, bioethics, cerebral palsy, electronic foetal monitoring, malpractice

\section{Background}

America and many of the world's industrialised countries have a cerebral palsy (CP) litigation crisis (1-6).

For almost fifty years trial lawyers and their CP courtroom experts have convinced judges and juries that physicians cause $\mathrm{CP}$ at birth (4). This causation theory is the millennium's second greatest hoax, the first being the hoax that electronic foetal monitoring (EFM) predicts and prevents $\mathrm{CP}(2,4,7)$. Together these hoaxes deceive millions more even than Orson Welles' famous 1938 War of the Worlds radio broadcast (8).

The direct victims of the CP-EFM hoaxes, birth related care givers, were at first truly exploited. Later, however, the caregivers, motivated by paralysing fear of CP lawsuits, and ignoring science and medical ethics, sought self-protection in EFM use rather than exposing and extinguishing the hoaxes

Authors: Thomas P. Sartwelle (tsartwelle@hdwlegal.com)), Hicks Davis Wynn, P.C, Houston, Texas, USA; James C Johnston (corresponding author - johnston@GlobalNeurology.com) Consultant Neurologist, Global Neurology Consultants, San Antonio, Texas, USA and Auckland, NEW ZEALAND; Berna Arda (Berna.arda@medicine.ankara.edu.tr) ,Professor and Chair, Department of Medical Ethics, Ankara University, TURKEY; Mehila Zebenigus (mehila@GlobalNeurology.com)), Professor, Department of Neurology, Addis Ababa University, ETHIOPIA.

To cite: Sartwelle TP, Johnston JC, Arda B, Zebenigus M. Cerebral palsy litigation after fifty years: a hoax on you. Indian J Med Ethics. 2020 Oct-Dec; 5(4)NS: 295-301.DOI:10.20529/IJME.2020.093.

Published online first on September 5, 2020

Manuscript Editor: Sunita S Bandewar

Peer Reviewers: Alastair MacLennan and an anonymous reviewer

(C) Indian Journal of Medical Ethics 2020
$(4,6,9)$. Thus, the CP-EFM hoaxes continue flourishing today, giving $\mathrm{CP}$ victims and their families false information and false hope of a safe birth $(4,7,9)$, costing society huge amounts of money $(2,4,6,7,10,11)$ misdirected to CP litigation instead of CP research, and $\mathrm{CP}$ care, costing physicians their ethical integrity (9), and costing mothers and children permanent physical and potential future harms from unnecessary EFM-induced caesarean sections (C-sections) $(2,4,7,11-17)$.

CP litigation's direct costs to society are measured in billions (26), much of it paid to trial lawyers and their courtroom experts and a comparatively smaller amount to the less than $10 \%$ of CP families who access the tort system $(6,11)$. Added to these direct costs are billions more in defensive medicine costs $(10,15,18,19)$, altering the standard of care to accommodate physicians' fears of lawsuits and administering prophylactic medical procedures solely to deter trial lawyers and lawsuits, which is birth care givers' response to allegations that they cause $\mathrm{CP}(4,6,9,12)$.

And while money in a limited resource endeavour like healthcare is of notable concern, the billions lost to the hoaxes are insignificant when compared to physicians' dishonouring the key ethical principles of autonomy $3 / 4$ informed consent, non-maleficence and beneficence $(9,12,16)$, and causing harm to mothers and babies by the continued knowing use of a scientifically destitute machine disguised as a safety device primarily for their own protection from lawsuits $(2,4,7,9-12)$.

The trial lawyers' major instrument of deception has been and is EFM $(4,7,9,10-12)$, an ironic touch since EFM is a direct descendant of medicine's most recognised symbol, the stethoscope (11), a symbol of physicians' dedication to healing, not harm; ethical integrity, not self-protection; and medicine's firm reliance on science not myths.

Banishing these hoaxes is an uncomplicated endeavour because the research and literature conclusively proving physician related birth events rarely cause $\mathrm{CP}$ and EFM does not predict or prevent $\mathrm{CP}$, has existed for decades and has recently been accumulating rapidly $(2,6,10,17,20-27)$. But, while physicians have long had the ability to dispel the CPEFM hoax they have mysteriously refused to use it $(4,11,16)$. And that is one of the questions answered here: Why not? A second question is also answered. How can CP-EFM litigation be stopped today? What effort will it take to see the beginning of the end of CP-EFM litigation?

The end of CP-EFM would not mean an end to EFM, which is a labour-saving device necessary to current day medicalised hospital obstetrics. It would, however, require physician honesty, as expectant mothers would finally have to be told the truth about EFM's limitations $(4,9,12)$, and 
that it does not predict or prevent $\mathrm{CP}$ or other neurologic maladies, and that EFM interpretation is more like an Ouija board than science. In other words, mothers will have to be given informed consent and the autonomy to choose how their labour is managed. But isn't that what bioethics has promised to all? $(9,28)$

\section{Myths beget a hoax}

CP has always bedeviled the world $(10,29,30)$. Its supposed causes were steeped in myths ranging from the evil eye, God's wrath, intercourse between witch and devil, to difficult teething $(10,29,30)$.

Nascent neurological explanations for what became known as CP began to be defined and accepted at least as early as the 1860's (10). CP became associated with asphyxia neonatorum - a lack of oxygen during labour and delivery $(10,29-31)$. This seemingly common-sense theory was coupled with another theory, arising shortly after the stethoscope was first used to listen to the foetal heart beats, that changes in foetal heart rate in labour is a reflection of foetal oxygenation status $(11,31)$. These theories led to the idea that monitoring the foetal heart rate could reliably detect a period of time before neurological damage occurred and thus intervening in labour if the heart rate exceeded the supposed "normal values" would rescue infants from $\mathrm{CP}$, all other birth-related neurological maladies including cognitive impairment, and death $(10,11,29-31)$.

These merged theories, and other thoughts about foetal acidosis, APGAR scores, umbilical cord blood gases, and further thoughts about neurodevelopmental prognostication (10), all scientifically unverified but accepted as true $(2,7,10-12)$, became the foundation for EFM technology which appeared in the late 1960s in labour rooms and shortly thereafter in courtrooms $(11,12)$, at a time when medical technology and medical machines were accepted by physicians and the lay public alike as necessary and essential in all aspects of medicine including the increasingly medicalised event- a normal birth $(4,10,12,28,30)$. EFM was introduced into clinical medicine and was hailed by physicians as deus ex machine (32), a miracle machine that would reduce by half $\mathrm{CP}$, epilepsy, and intellectual disability (33), save as many as 20,000 babies every year, reducing the number of injured babies by $50 \%$ (34-36)

Almost overnight, EFM became the standard of care in hospitals around the world. And not even one randomised EFM clinical trial had yet occurred $(2,4,7,10-1234-36)$.

And not long after obstetricians heralded EFM as the predictor of birth asphyxia and C-sections as the saviour of birth-injured babies, trial lawyers began asking obstetricians in CP lawsuits why a particular baby had CP in spite of the marvelous machine that predicted asphyxia $(4,7,9-12)$.- The question why a C-section was not used to save a baby from lifelong neurological devastation became the focal point of every CP lawsuit $(4,7,9-12)$ And a cottage industry was born (no pun intended) that has blossomed into a worldwide crisis today (1-6).

Now, fifty years after EFM became the obstetrical standard of care in virtually every industrialised country in the world, and after CP lawsuits have been commonplace for almost the same amount of time, independent researchers around the world have proven the medical theories supporting EFM use and $\mathrm{CP}$ causation to be not much more than a scientific hoax (1-4,9-12, 20-27,34-42). In essence, if "EFM predicts asphyxia and C-sections prevents $\mathrm{CP}^{\prime \prime}$ had been a space rocket, humankind would never have got off the ground much less walked on the moon.

So, the question is, how, in the second decade of the twentyfirst century, a century of advanced medical and scientific enlightenment, can a proven hoax like EFM survive in the world's labour rooms and courtrooms?

\section{Undue influence}

Trial lawyers, the tort system, and medical malpractice lawsuits have been around for centuries (43). And while doctors even in the nineteenth century complained that they were being persecuted by trial lawyers, the reality was that medical malpractice suits were relatively uncommon as compared to other types of personal injury lawsuits (43).

Uncommon that is until the 1950s $(10,11,43)$. As a result of numerous sociological attitudinal changes following World War II including massive court-made tort liability expansion and liberalised evidence law (43), changes in society's injury responsibility attitude, expanded lawyer advertising, and the death of medical paternalism $(4,9,11)$, the frequency and severity of physician malpractice lawsuits suddenly, rapidly accelerated $(4,10,11)$. Claims and suits against physicians achieved unprecedented levels as did the injury awards, precipitating the first of numerous insurance availability crises beginning in the early 1970 s $(10,11)$.

Following the first physician insurance crisis, demands for national and state malpractice reforms and no-fault schemes have continually permeated the medical literature, mostly to no avail $(4,6,11,44-45)$ Rather than meaningful reforms, the medical tort system (the legal system dealing with medical malpractice causes of action) continues to expand with increasing case numbers, verdicts, and settlements. The primary reason for the expanding malpractice scene and the failure of tort reform (proposed changes in the civil justice system that directly reduce tort litigation or damages) in most of the world's countries is trial lawyers (4).

Trial lawyers have accumulated vast wealth from the modern tort contingent fee system and have used that wealth partly to successfully block medical malpractice reforms $(46,47)$. This success has included maintaining the lucrative EFM-birth asphyxia-CP cases within the high verdict value fault finding systems of most countries $(4,6,7,10)$. But $C P$ cases are of relative recent origin. Before EFM, birth asphyxia was an explanation, not an indictment. 


\section{Theories become accusations}

Before the 1970s, CP lawsuits were rare to non-existent. Birth asphyxia as CP's cause was accepted as a scientific fact primarily because there was no obstetrical blame associated with a CP child's birth $(10,29,30)$. Birth asphyxia was the explanation doctors gave to heartbroken parents (11). Additionally, auscultation by the human ear, the only foetal heart monitoring method available, left no trace and an obstetrician's memory that the foetal heart tones were normal was not subject to dispute even by lawyers' cross examination (11).

But EFM left a trail. A permanent paper trail. A trail that could be preserved. And then re-analysed in a courtroom years, even decades after birth, by hired EFM courtroom "experts" (48) medical witnesses using the century old unproven asphyxia theory, who were willing to swear that the baby would have been neurologically normal if only the obstetrician, midwife, or nurses, or all of them, had recognised the precise moment on the EFM strip that the baby suffered the birth asphyxia that caused the CP (11).

While the very first EFM verdict is unknown (49), what is known is that by the early 1980s, clever trial lawyers, taking advantage of the EFM-CP myths, were aware of EFM's million-dollar potential, had cultivated their courtroom EFM "experts,"(48) and begun to profit from what became common high stake, high verdict, lawsuits that routinely were part of the annual list of top trial verdicts $(50,51)$

Trial lawyers' CP-EFM reasoning was simple: EFM detected asphyxia; there was a limited window of opportunity after asphyxia was detected when the foetus could be quickly delivered by $\mathrm{C}$-section or instrumented delivery and saved from irreversible $\mathrm{CP}$ and brain damage. Thus, if a child had $\mathrm{CP}_{\text {, }}$ or any other neurological abnormality, someone must have been inattentive of the machine's signals or ignorant of what the machine was revealing. Either way, doctors and hospitals would have to pay for the inexcusable lifelong neurological devastation. Usually unmentioned, was the fact that the lawyer would first be paid $40-50 \%$ of the money received.

This trial lawyer reasoning was not original. It was based on the "facts" that EFM inventors $(33,52)$ and their disciples published in various books and journal articles proclaiming EFM theory as scientific fact $(33,52-54)$. In a short time, more and more EFM "experts" emerged publishing "peer reviewed" books and articles validating EFM science and how quick delivery when asphyxia was detected prevented CP $(11,22,34,35)$.

And in courtrooms around the world paid "courtroom experts" relying on the articles and books, many of which they had themselves written $(34,35)$ delivered a neurologically perfect infant most often by $\mathrm{C}$-section, something the defendants could have done but for the defendants' ignorance or inattention. These experts delivered thousands of CP babies by $\mathrm{C}$-section in the courtroom, each one neurologically perfect, and neither mother nor baby ever had even one complication.
Ironically, the EFM inventors fooled not only the realworld caregivers but they fooled the trial lawyers and their courtroom experts as well. And the inventors profited handsomely from the hoax.

\section{The machine that goes "ping"}

The role of EFM in birth is reminiscent of the Monty Python film The Meaning of Life, Part I, The Miracle of Birth, where after filling the delivery room with expensive equipment so there is barely room for the doctors and nurses to move, the doctors notice a slight oversight: they have forgotten the patient (55). When EFM was introduced into clinical medicine, Corometric Medical Systems was one of the first companies manufacturing, promoting, and selling EFM machines. Hospitals worldwide enthusiastically embraced EFM with its inventors' promise of near perfect obstetrical outcomes $(11,12,34,35)$. With its lights, dials, digital readouts, and reams of graph paper that silently but instantaneously and permanently recorded heretofore unobtainable data from the entire birth process no matter how long the labour, EFM was finally ushering obstetrics into the medical technology age, a frenzy that had overtaken almost all of medicine. EFM gave obstetrics a modern aura of technological invincibility. Most obstetricians and hospital administrators cared little that EFM was based not on clinical trials and science but on assumptions, anecdotes, and personal observations, tainted by undisclosed avarice $(34,35,56,57)$.

Corometric was founded by Edward Hon, Yale physician and engineer who later joined the University of Southern California (USC). Hon was one of the primary EFM inventors. Hon and his colleagues, who originally tested the machine, conducted the "studies," and wrote the favourable journal articles used to convince hospitals to purchase the machines, were undisclosed Corometric Board of Directors members, stockholders, investors, and patent holders $(34,35,56,57)$. When Hon moved his research to USC, he and his colleagues continued publishing favourable EFM articles and sales continued increasing at a phenomenal rate. Hon and colleagues' studies were so impressive $\mathrm{NIH}$ funded one million tax dollars of evaluative research at USC between 1971 and 1975 (34,35). In a 1969 Life Magazine article, Hon claimed that $90 \%$ of all foetal distress was caused by umbilical cord compression and, therefore, EFM monitoring would save 20,000 babies per year and reduce the number of injured babies by $50 \%$ (34).

What was not published was the fact that Corometric was also a prime funding source for Hon's research and writing, as well as the favourable research and writing of his colleagues who were undisclosed Corometric stockholders, investors, and patent owners $(34,35,57)$. By 1975 EFM was so entrenched in clinical practice and accepted as a necessary safety device for all labours, that USC rejected a proposed EFM randomised controlled trial (RCT) on the ground that EFM was necessary for a safe birth and withholding EFM from the control group would be unethical $(12,34,35)$. Corometric's EFM sales 
continued to be spectacular, and when Corometric was eventually sold, Hon and his insiders, including prominent Yale and Harvard physicians, held more than half the stock $(34,35)$.

Ironically, despite millions of public and undisclosed Corometric dollars provided for EFM research, not even one RCT had been accomplished by the EFM inventors or their acolytes $(10,12,34,35)$. When the first RCT was published in 1976 by a Corometric outsider and other outsiders began to notice that EFM's foundational principles were weak and its use caused more harm than good, the obstetrical community reacted with caustic outrage and ad hominem attacks on the messengers $(10,34,35)$.

\section{Shooting the messengers}

The literature is replete with evidence of personal and professional retaliation against those physicians questioning EFM (56). Before 1976 Albert Haverkamp, a Denver obstetrician, readily embraced EFM $(34,35)$. He became concerned that EFM's usefulness was not appreciated by some obstetricians and by many labouring women who were rejecting EFM. So Haverkamp began the first RCT to prove EFM's efficacy to the skeptics $(35,57,58)$. He was surprised by his results, however. Comparing 483 patients monitored with EFM and auscultation, he found no EFM advantage. There was, however, a decided EFM negative: EFM C-sections were $16.5 \%$ of patients monitored with EFM, but only $6.8 \%$ for those with auscultation $(34,35,57,58)$.

Haverkamp then had an even bigger surprise. His study, presented at a medical conference just prior to its 1976 publication, was immediately attacked as outdated by a panel of EFM "experts" who contended that all women in labour must be monitored with $\operatorname{EFM}(34,35)$.

Shortly after Haverkamp's antagonistic reception, two epidemiologists from the Department of Health Education and Welfare began a review of $600 \mathrm{EFM}$ published articles and books in order to assess EFM's efficacy, safety, and costs, as well as the social implications of using technology in childbirth $(34,35)$. In a first ever systematic review of a healthcare technology (35), they concluded there was little if any benefit to widespread EFM use but there were substantial risks from the significantly increased C-sections induced by EFM and substantial added annual costs related to the additional C-sections, suggesting EFM may be doing more harm than good (59). The formal report was published as a medical journal article in 1979 (60). The obstetrical community outrage was instantaneous $(34,35)$.

The vehement attacks on the report and the authors personally by prominent and unknown obstetricians were like those on Haverkamp and were relentless (35). Ironically, the attackers had no RCTs with which to counter the evidenced based EFM criticisms. They resorted to impressions and personal experience as better evidence than RCTs $(34,35)$.

These early attacks portended the arguments obstetricians would continually make for the next four decades. As the scientific evidence against asphyxia as a CP cause and against EFM as the predictor of $C P$ and $C$-sections as preventing $C P$, EFM proponents ignored facts, science, medicine, RCTs, and bioethics, and simply continued in the Hippocratic paternalism posture they had known for so long (9), insisting EFM was a device necessary for safe birth. Although the uncontradicted evidence said otherwise, common sense and rationality became obstetricians' natural enemies when it came to EFM-CP.

\section{Hear no evil, see no evil}

For every complex problem there is a solution that is simple, neat, and wrong.

HL Mencken

From the late 1960s until today scientific research throughout the industrialised world has time and time again proven that physicians and nurses rarely cause CP $(2-4,7,17,22-27)$ and EFM is unscientific $(1,2,4,7,10-12,17,20-23)$ not the God in a machine (32) that obstetricians hoped for. In fact, very recently the very foundation of EFM - the cause of and meaning of foetal heart decelerations - has been proven to be wrong $(61,62)$.

Scientific proof discrediting the EFM-CP hoaxes slowly accumulated in every decade since 1960. This proof was published in multiple government, university, and privately sponsored studies, twelve RCTs, dozens of meta analyses, Cochran Collaboration Reviews, ACOG-AAP Task Force Reports, US Preventive Task Force Reports, editorials, and comments, in virtually every major medical journal in the world $(4,7,9,11,12,16,31,46)$. The evidence has been readily accessible to every birth healthcare giver, and every lawyer, as well as the public and expectant mothers through newspaper articles, magazine articles, books, and birth related organisations (12, $28,56,57,63-66)$.

Yet, during this same time span, CP litigation exploded in volume and expense and physicians, nurses, midwives, and hospitals were routinely held liable in court cases of causing CP $(2,4,7,10-12)$. The prime instrument of blame for this was the EFM machine $(2,4,7,10-12)$. Ironically, physicians' EFM use, along with EFM induced C-sections, also increased each year along with hospitals' investment in more and more EFM monitoring equipment until worldwide EFM was used to monitor almost every birth in the industrialised world $(2,4,7,10-12)$.

At the same time, mothers were not given any choice in EFM monitoring or informed consent, nor were they told that EFM was doing more harm than good, or that EFM was unnecessary for a safe birth $(9,12,16,46,63-66)$. This silence on the part of obstetricians was occurring despite pleas by some physicians, professional organisations, and even private citizens for obstetricians to follow bioethical autonomy and allow mothers an informed choice for foetal monitoring $(9,12,16,35,59,60,63-$ 66). Strangely, medical ethicists remained completely silent (9).

The question that should trouble everyone living in enlightened modern world societies where bioethics demands respect for individual choice, and where science permeates 
our lives and informs our actions, is how EFM, a documented unscientific machine, has been allowed by physicians and judges to dominate obstetrical and judicial decisions for the last half century?

\section{An age of unreason?}

Sometimes people don't want to hear the truth because they don't want their illusions destroyed.

Friedrich Nietzsche

"No one gets sued for doing a C-section. . . They do get sued . . . for not intervening."(64) So goes the thought process of the vast majority of obstetricians, a mantra passed on to each generation for half a century $(7,19)$.

And therein lies the answer to the question why EFM, despite evidence of uselessness, dominated labour-delivery rooms and court decisions for fifty years; and why women and babies have been at risk for serious harms from unnecessary C-sections: obstetricians. Obstetricians and their irrational, incoherent, muddled, disjointed fear of CP lawsuits $(4,11,12,19,28)$.

Physicians often blame the court system, trial lawyers and their "expert witnesses" for the dramatic high dollar verdicts and settlements that have become so commonplace in medicine and pharmaceuticals in the last half century $(11,43)$. And they certainly deserve most of the blame for what many believe is a litigation system that is not only more like a government sponsored lottery but is also illogical, unpredictable, cumbersome, and slow and in desperate need of reform, especially when it comes to complex medically related topics $(11,43,67)$. But when it comes to CP-EFM litigation, healthcare providers have no one but themselves to blame for the fiftyyear litigation crisis.

The golden age of trial lawyers and their paid experts began in the 1960s as courts liberalised legal liability theories adding heretofore unrecognised recovery theories against myriad defendants including healthcare providers, vaccine makers, and manufacturers of drugs and medical equipment $(11,43)$. Liberalised evidence rules followed allowing trial lawyer-paid experts to express opinions on ultimate issues - "say whatever you want opinions" - like causation. Opinions based on little more than personal beliefs, personal experiments and theories, many unpublished and unvetted by peer review (43).

Billions were paid to "victims" and mostly their lawyers for multiple dozens of supposedly defective, hurtful medical modalities (68) DPT vaccines, Bendectin, breast implants, thimerosal in vaccines, MMR causing autism (69-73). What most of these had in common was that five, ten, fifteen years later real science caught up with the paid experts proving that the sworn, paid for causation testimony was not only unscientific but dead wrong (68-73). By then, however, the damage was done.

CP-EFM litigation began in exactly the same way. Using the theories of the EFM inventors, the paid experts swore in courtrooms around the world that EFM predicted asphyxia and C-sections prevented CP $(4,9,16,46,74)$. In a short time, however, science began to catch up and published research was proving $\mathrm{CP}$ was rarely caused by birth care providers and EFM was not predicting or preventing $C P$.

The difference between DPT, Bendectin, breast implants, etc, was that obstetricians rather than embracing the exonerating research vehemently rejected it in favour of their original illusion that CP was primarily caused by asphyxia and EFM was in fact the deus ex machina that recused babies in distress. Fear of lawsuit originally drove EFM false positive mandated C-sections and continues driving obstetrical C-section decisions fifty years later. Physicians are knowingly subjecting mother and babies to current and future risks connected to C-sections without informed consent, despite a promise to do no harm, all because they fear lawsuits more than they respect patients' autonomy or their own ethics.

\section{Unraveling the Gordian knot}

After rejecting CP-EFM science for fifty years, can birth related caregivers undo their self-made CP-EFM litigation Gordian knot? The answer is yes. The solution is simple. It is the collective will that is problematic. Caregiver voices have called attention to the EFM hoax suggesting that the powers that be do something about the litigation problem $(2,4,5-7,10-12,38)$; but the leaders of the world's birth related professional organisations (BRPO) have apparently been uninterested in solutions, otherwise something would have been done before now.

All that is required is for BRPO to change the standard of care $(4,7)$, and to formally declare that EFM is unreliable as currently used, does not predict or prevent $C P$, and is not the standard of care for normal labour. In turn, such a declaration will impact litigation because physicians must generally testify to a standard of care in a lawsuit. It is the physician who set the SOC in the courtroom, not judges or lawyers $(4,7,43)$.

In fact, some in the obstetrics world have already suggested EFM standard of care be changed for low risk pregnancies. In the forefront has been the UK's National Institute for Health and Care Excellence (NICE). Since 2001 NICE has recommended EFM not be used in normal pregnancies (75). ACOG recently made a similar recommendation (76). ACOG finally formally recognised EFM has not reduced $C P$ or perinatal death and has increased C-sections. ACOG now recommends women with low risk pregnancies be given an informed choice between EFM or intermittent auscultation (76). Neither the NICE nor ACOG statements preclude selected antenatal monitoring in particular for high risk cases, and future statements can specifically ensure this option remains open.

But what is needed to change the standard of care worldwide and end EFM-CP litigation is not piecemeal NICE-ACOG recommendations that physicians do not follow. Rather what is needed is an authoritative medical body, preferably an International Task Force, writing in declarative sentences, to author a clear, unambiguous, coherent, plainly worded 
statement, understandable to judges, jurors, other lay persons, as well as expectant mothers, summarising the current EFM-CP medical scientific evidence proving $\mathrm{CP}$ is not solely caused by birth asphyxia and that EFM is unreliable and has never been able to and cannot today predict or prevent CP or any other neurological malady.

An authoritative statement would enable defendants to bring Daubert junk science challenges $(4,7,43)$ against the same few EFM courtroom experts who continue to testify EFM predicts and prevents CP (48). EFM junk science challenges are not routine today because there are no specific, comprehensive, unambiguous, evidence based CP-EFM statements analysing contemporary clinical CP-EFM evidence and weeding out the stale EFM literature and theories of the past fifty years which are inappropriately relied upon by trial lawyer experts to perpetuate the hoax. Challenging EFM courtroom experts would mean the beginning of the end of CP-EFM litigation $(7,11,43)$.

If the EFM standard of care were changed, EFM can still be used in labour-delivery rooms. To do so, however, mothers will have to give true informed consent and be told EFM is not a safety device but a labour-saving device whose interpretation is art not science and that EFM may help the physician make choices, but the choices are not scientifically verified. This is what Banta and Thacker concluded in 1978-79 $(59,60)$. It is still true today. And mothers deserve to be told the truth. Most will choose EFM if their doctors believe it is helpful, but the choice should belong to mothers not physicians (9).

\section{Conclusion}

EFM began as a noble attempt to conquer a centuries old plague - cerebral palsy - but has been turned into a nightmare for birth caregivers and increased the chances that women and babies may experience harm from what should be a happy experience. While trial lawyers certainly deserve the blame for starting, perpetuating, and profiting from the EFM-CP hoax, physicians share equally in the blame for these half century old hoaxes that have become a shameful stain on an honourable profession (77). Physicians' vincible ignorance in this continuing hoax is apparent for all to see. But to paraphrase Jeremiah, there are none so blind as those who will not see.

The solution to the current EFM-CP conundrum has been and still is a simple one and is available today. Physicians can give real meaning to the principle of autonomy in childbirth by simply changing the EFM standard of care. It can be done and it should be done now. It merely takes determination to acknowledge the obvious - EFM harms mothers and babies - and acknowledge that medicine's first obligation is to do no harm.

\section{Conflicts of interest and funding: None declared}

\section{References}

1. Sabiani L, Le Du R, Loundou A, D'Ercole C, Bretelle F, Boubli L, et al. Intra- and -++interobserver agreement among obstetric experts in court regarding the review of abnormal fetal heart rate tracings and obstetrical management. Am J Obstet Gynecol 2015; 213(6):856.e1-e8.

2. MacLennan AH,Thompson SC, Gecz J. Cerebral Palsy: Causes, pathways, and the role of genetic variants. Am J Obstet Gynecol. 2015;213(6):77988.

3. Donn SM, Chiswick ML, Fanaroff JM. Medico-legal implications of hypoxic-ischemic birth injury. Sem Fetal Neonatal Med. 2014;19(5):31721.

4. Sartwelle TP, Johnston JC. Cerebral palsy litigation: Change course or abandon ship.J Child Neurol. 2015;30(7):828-41.

5. Wise J. Litigation in maternity care is rising, says national audit office. BMJ 2013;347:f6737.

6. MacLennan AH. A 'no fault' cerebral palsy pension scheme would benefit all Australians. Aust NZ J Obstet Gynecol. 2011;51(6):479-84.

7. Nelson KB, Sartwelle TP, Rouse DJ. Electronic fetal monitoring, cerebral palsy, and caesarean section: Assumptions versus evidence. BMJ. 2016;355:i6405.

8. Cantril $H$, Hazel $G$, Herzog $H$. The invasion from Mars: A study in the psychology of panic with a complete script of the famous Orson Welles broadcast. Princeton, NJ: Princeton University Press; 1940.

9. Sartwelle TP, Johnston JC, Arda B. A half century of electronic fetal monitoring and bioethics: Silence speaks louder than words. Matern Health, Neonatol Perinatol. 2017;3(21):1-8.

10. Obladen M. From "Apparent Death" to birth asphyxia: A history of blame. Pediatr Res. 2018;83(2):403-11. DOI:10.1038/pr.2017.238.

11. Sartwelle TP. Electronic fetal monitoring: A bridge too far. J Legal Med. 2012;33:313-79.

12. Wolf JH. Risk and reputation: Obstetricians, cesareans, and consent.J Hist Med Allied Sci. 2018;73(1):7-28.

13. Schlinzig $T$, Johansson $S$, Stephansson $O$, Hammarström L, Zetterström $\mathrm{RH}$, von Döbeln $\mathrm{U}$, et al. Surge of immune cell formation at birth differs by mode of delivery and infant characteristics---A population-based cohort study. PLOS One. 2017;12(9):e0184748.

14. Friedrich MJ. Unraveling the influence of gut microbes on the mind. JAMA. 2015;313(17):1699-1701.

15. Neu J. The pre-and-early postnatal microbiome: Relevance to subsequent health and disease. Neo Reviews. 2013;13(12):e-592-e-599.

16. Sartwelle TP, Johnston JC, Arda B. Perpetuating myths, fables, and fairy tales: A half century of electronic fetal monitoring. Surg $J(N Y)$. 2015;1(1):e28-e34.

17. Badawi N, Keogh JM. Causal pathways in cerebral palsy. J Pediatr Child Health. 2013;49:5-8.

18. Anderson RE. Billions for defense: The pervasive nature of defensive medicine. Arch Inter Med. 1999;159:2399-402.

19. Minkoff H. Fear of litigation and cesarean section rates. Semin Perinatol. 2012;36:390-394.

20. Constantine MM, Saade GR. The first caesarean: Role of "fetal distress" diagnosis. Semin Perinatol. 2012;36:379-383.

21. Grimes DA, Peipert JF. Electronic fetal monitoring as a public health screening program: The arithmetic of failure. Obstet Gynecol 2010;116(6):1397-400

22. MacLennan $A$, Hankins $G$, Speer N. Only an expert witness can prevent cerebral palsy. Obstet Gynecol 2006;8(1):28-30.

23. MacLennan $A$, Nelson $K B$, Hankins $G$, Speer $N$. Who will deliver our grandchildren? JAMA. 2005; 294(13): 1688-90.

24. Nelson KB, Blair E. Prenatal factors in singletons with cerebral palsy born at or near term. New Engl J Med. 2015;373(10);946-53.

25. O'Callaghan M, MacLennan A. Cesarean delivery and cerebral palsy: A systematic review and meta-analysis. Obstet Gynecol. 2013;122(6):116975.

26. Ellenberg $\mathrm{JH}$, Nelson KB. The association of cerebral palsy with birth asphyxia: A definitional quagmire. Dev Med Child Neurol. 2013;55:21016.

27. Nelson KB, Ellenberg JH. Antecedents of cerebral palsy multivariant analysis of risk. New Eng J Med. 1986;315:81-6.

28. Spector-Bagdady K, DeVries R., Harris LH, Low KL. Stemming the standard-of-care SPRAWL: Clinician self-interest and the case of electronic fetal monitoring. Hastings Cent Rep. 2017;47(6):16-24.

29. Obladen M. Lame from birth: Early concepts of cerebral palsy. J Child Neuro. 2011;26(2):248-56.

30. Beller FK. The cerebral palsy story: A catastrophic misunderstanding in obstetrics. Obstet Gynecol Survey. 1995;50:83-6. 
31. Sartwelle TP Defending a neurologic birth injury: Asphyxia neonatorum redux. J Legal Med. 2009;30:189-247.

32. Greene MF. Obstetricians still await a deus ex machina. New Engl J Med. 2006;355(21):2247-8.

33. Quilligan EJ, Paul RH. Fetal monitoring: Is it worth it? Obstet Gynecol. 1975;45(1):96-100.

34. Graham EM, Peterson SM, Christo DK, Fox HE. Intrapartum electronic fetal heart rate monitoring and the prevention of perinatal brain injury. Obstet Gynecol. 2006;108(3):656-66.

35. Banta DH, Thacker SB. Historical controversy in health care technology assessment: the case of electronic fetal monitoring. Obstet Gynecol Surv. 2001;56(11):707-19.

36. Martin CB Jr. Electronic fetal monitoring: a brief summary of its development, problems and prospects. Eur J Obstet Gynecol Reprod Biol. 1998;78:133-40.

37. Alfirevic Z, Devane D, Gyte GML, Cuthbert A. Continuous cardiotocography (CTG) as a form of electronic fetal monitoring (EFM) for fetal assessment during labour. Cochrane Database Syst Rev. 2017 2(2): CD006066.DOI:10.1002/14651858.CD006066.pub3.

38. Maso G, Piccoli M, DeSeta F, Parolin S, Banco R, Camacho-Mattos L, et al. Intrapartum fetal heart monitoring interpretation in labour: a critical appraisal. Minerva Ginecol. 2015;67:65-79.

39. American College of Obstetricians and Gynecologists, American Academy of Pediatricians. Executive Summary: Neonatal encephalopathy and neurologic outcome. 2nd ed. Obstet Gynecol. 2014

40. Clark SL, Nageotte MP, Garite TJ, Freeman RK, Miller DA, Simpson KR, et al Intrapartum management of category II fetal heart rate tracings: toward standardization of care. Am J Obstet Gynecol. 2013;209(2):89-97.

41. Illingworth RS. Why blame the obstetrician: A review. Brit Med J. 1979;1(6166):797-801.

42. Nelson KB, Dambrosia JM, Ting TY, Grether JK. Uncertain value of electronic fetal monitoring in predicting cerebral palsy. $N$ Engl J Med. 1996;334(10):613-618.

43. Johnston JC, Sartwelle TP. The expert witness in medical malpractice litigation:Through the looking glass. J Child Neurol. 2013; 28:484-501.

44. American College of Physicians. Medical liability reform: Innovative solutions for a new health care system. Policy Paper. Philadelphia: American College of Physicians; 2014.

45. O'Connel J, Robinette CJ. A recipe for balanced tort reform. Durham, NC Academic Press; 2008

46. Sartwelle TP, Johnston JC. Cerebral palsy and electronic fetal monitoring Rearranging the Titanic's deckchairs. J Child. Develop Disord 2016;2:1-10.

47. Sloan FA, Chepkelm LM. Medical malpractice. Cambridge MA: MIT Press 2008.

48. Kesselheim AS, Studdert DM. Characteristics of physicians who frequently act as expert witnesses in neurologic birth injury litigation. Obstet Gynecol. 2006;108(2):273-9.

49. Jonas $G$. This man makes millions suing Ob/Gyns.Olender.com. [originally published 1991 Jan in OBG Management magazine [cited 2016 Mar 20]. Available from: https://www.olender.com/articles/this-man-makesmillions-suing-ob-gyns/

50. Lucchese DR. Defending the perinatal brain injury lawsuit. For The Defense. 2007:49:65-69.

51. Stanley F. Litigation versus science: what's driving decision making in medicine? UWA Law Review. 1995; 25:265-82.

52. Hon $\mathrm{EH}$. The electronic evaluation of the fetal heart rate: preliminary report. Am J Obstet Gynecol. 1958; 75:1215-30.

53. Kubli FW, Hon EH, Khazin AF, Takemura $\mathrm{H}$. Observations on heart rate and $\mathrm{pH}$. in the human fetus during labor. Am J Obstet Gynecol 1969;104(8):1190-1206

54. Paul RH, Suidan AK, Schifrin BS, Hon EH. Clinical fetal monitoring. VII. The evaluation and significant of intrapartum baseline FHR variability. Am J
Obstet Gynecol. 1975;123(2):206-210.

55. Python M. The Meaning of Life - Birth Part I. 1983 [accessed 2017 Nov 30]. Available from: https://video.search.yahoo.com/search/video?fr=mcafe e\&p=Monty+Python $\% 2 C+$ The+Meaning +of +Life $\% 2 C+$ Part $+1 \% 2 C+$ Th e+Miracle+of+Birth\#id=4\&vid=577cd03bda0d25c79f324694d8f91687 \&action $=$ click

56. Goer H, Romano A. Optimal care in childbirth. Seattle WA: Classic Day Publishing; 2012. Chap. 10. Electronic fetal monitoring (cardiotocography): minding the baby pp. 223-50.

57. Block J. Pushed: The painful truth about childbirth and modern maternity care. Cambridge, MA; DaCapo Press; 2007. Chap. 1. Arranged birth. pp. 31-8.

58. Haverkamp AD, Thompson HE, McFee JG, Cetrulo C. The evaluation of continuous fetal heart rate monitoring in high risk pregnancy. Am J Obstet Gynecol. 1976;125(3):310-20.

59. Banta HD, Thacker SB. Costs and benefit of electronic fetal monitoring Hyattsville, MD: Nat'I Center Health Services Research; 1978.

60. Banta HD, Thacker SB. Assessing the costs and benefits of electronic fetal monitoring. Obstet Gynecol Survey. 1979;34:627-42.

61. Lear CA, Galinsky R, Wassink G, Yamaguchi K, Davidson JO, Westgate $\mathrm{JA}$, et al. The myths and physiology surrounding intrapartum decelerations - the critical role of the peripheral chemoreflex. J Physiol. 2016;594(17):4711-25

62. Lear CA, Galinsky R, Wassink G, Mitchell CJ, Davidson JO, Westgate JA, et al. Sympathetic neural activation does not mediate heart rate variability during repeated brief umbilical cord occlusions in near-term fetal sheep. J Physiol. 2016;594(5):1265-77.

63. Women's Health and Education Center. Health Care Policies \& Women's Health. 2012 [cited 2017 Oct 25]. Available from: http://www. women'shealthsection.com/content/heaVhea1020.ph03

64. Lake N. Labor interrupted. Harvard Magazine. 2012 Nov-Dec: 21-26. Available from: https://www.harvardmagazine.com/2012/11/laborinterrupted

65. Berlatsky N. The most common childhood practice in America is unnecessary and dangerous. New Republic. 2015 Aug13[cited 2016 Mar 28]. Available from: https://newrepublic.com/article/122532/mostcommon-childbirth-practice-us-unnecessary-dangerous

66. Morris T. Cut it out: The c-section epidemic in America. New York, NY: New York University Press; 2013.

67. Glendon MA. A nation under lawyers. Boston MA: Harvard University Press; 1996.

68. Huber PW. Galileo's revenge. New York, NY: Basic Books. 1993.

69. Offit PA. Deadly choices. New York, NY: Basic Books; New York, NY. 2011.

70. Offit PA.Autism's false prophets. New York, NY : Columbia University Press; 2008.

71. Angell M. Science on trial. New York, NY:WW Norton \& co; 1996.

72. Mnookin S. The panic virus. New York, NY: Simon \& Schuster; 2011.

73. Goldberg R. Tabloid medicine. Kaplan Publishing. New York, NY. 2010.

74. Localio AR, Lawthers AG, Bengtson JM, Hebert JL, Weaver SL, Brennan TA, et al. Relationship between malpractice claims and cesarean delivery. JAMA. 1993;269(3):366-73.

75. National Institute for Health and Care Excellence, Intrapartum care for health women and babies. 2017 Feb 21[cited 2017 Feb 21]. Available from: https://www.nice.org.uk/guidance/cg190/chapter/ Recommendations\#monitoring-during-labour).

76. Committee on Obstetric Practice, American College of Obstetricians and Gynecologists. Approaches to limit intervention during labor and birth. Committee Opinion no.687.2017.

77. Sartwelle TP, Johnston JC. Continuous electronic fetal monitoring during labor: A critique and reply to contemporary proponents. Surg J. 2018; 4:e23-e28. 